\title{
A View on Russian Economy Mid-term Perspectives
}

\author{
By Sergey Drobyshevsky
}

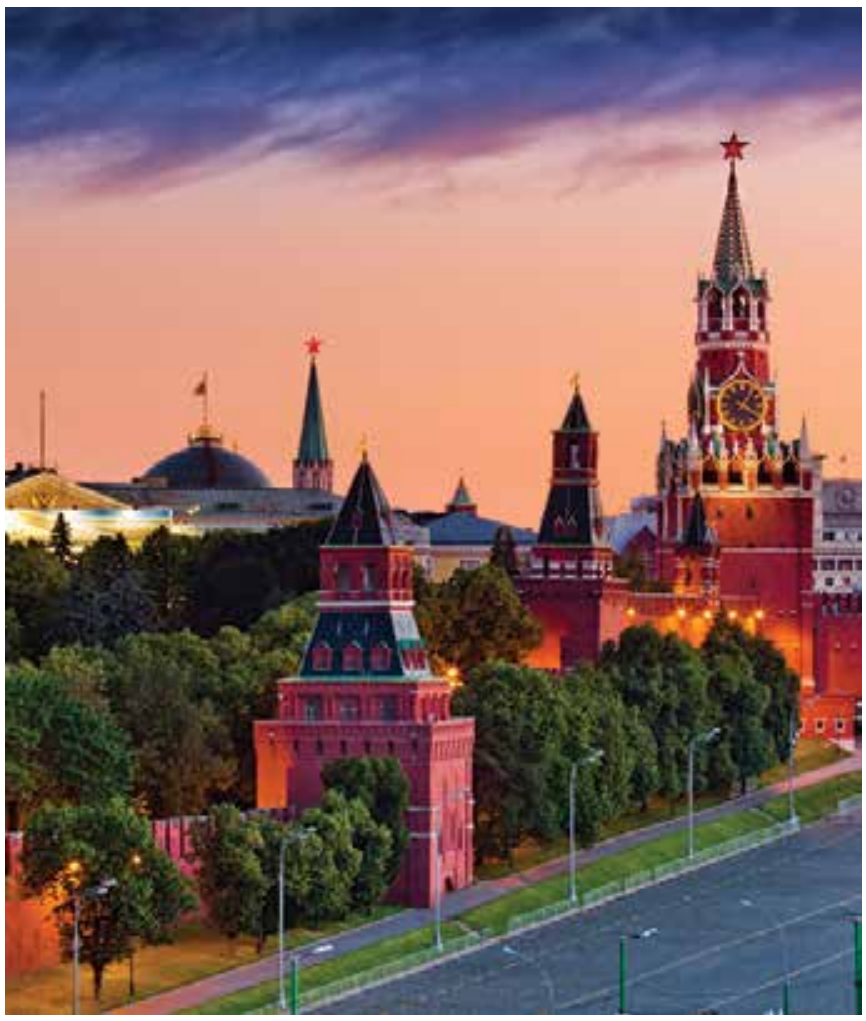

There are a lot of arguments illustrating the low probability of fast and stable growth of the Russian economy in midterm perspective. Does it mean that the economy is doomed and Russia will go down in the list of top economies? The answer - Yes and No. Sergey Drobyshevsky explains why.

$\mathbf{R}$ ussia demonstrated outstanding economic results through the 2000s as the oil price growth and global investment boom lasted. The 2008-2009 crisis happened to be too tough - the real GDP fell by 7,9\% in 2009 , and was one the deepest GDP drops at that time. However, prices for oil recovered swiftly and have been maintaining around $\$ 100$ per barrel and above, and Russia survived the crisis without public debt increase and kept the government budget nearly balanced. The financial sector also had minor losses (some second-order commercial banks failed in 2009, but those cases did not have serious implications), and inflation confidently went down to a one-digit range for the first time since the market reform started. But, in the second half of 2012 the economy's growth rate is slowing down and now tends to be close to zero: Russia is ready to enter stagnation.

\section{Oil Prices and Commodity Economy}

We use to consider Russia as a commodity state whose welfare was mainly based on extraction and export of hydrocarbons. Well, Russia has one of the biggest oil and natural gas endowments, virtually dominates at the European crude oil and natural gas markets and actively builds up export of oil and gas to China South East Asia. Export of oil and gas accounts for $2 / 3$ of exports, and taxes from those industries provide more than $50 \%$ of federal budget revenues. But, the world is changing, traditional assumptions are no longer valid, and the oil- and gas sector is not a key driver of Russian economic growth anymore.

First, the Russian economy happens to be too big and (it sounds strange) well diversified, to benefit as oil prices are high. According to Gaidar Institute's estimates, the total input of oil and gas sector to Russia's GDP peaked at 2005 - ca. 25\% of GDP, but afterwards this figure was permanently shrinking and now the industry adds at most $21 \%$ of GDP. In fact, the oil extraction is virtually constant since 2005 - around 500 $\mathrm{mln}$. tons a year - i.e. the industry's real output has not grown for 10 years, but the GDP has grown, obviously, due to growth in other industries and services. We do not have any grounds to expect an increase in real output in the oil and gas industry in next years, and, according to our estimates, by 2020 the share of oil and gas industry in GDP will fall to $18,0-18,5 \%$ of GDP, i.e. a quarter less than in 2005.

Second, oil and natural gas are not the only commodities exported by Russia. The second exported goods are metals (various non-ferrous metals and steel as well), summing up ca. $20 \%$ of Russia's export. Unlike oil prices, prices for most metals dropped considerably in 2013 as well as physical volumes, which decreased both domestically and exported. We did not make a similar estimation of the broad metallurgy industry input to GDP, however, this industry is very important for Russian economies in terms of employment and impact on particular Russian regions.

Third, nobody should overestimate the impact of high oil prices solely on the Russian economy in previous times.

\section{Limits of Growth Potential}

Many politicians and investors got accustomed to the fast growth of the Russian economy in the 2000s (recall Goldman Sachs's forecast on growth in BRIC economies). That's why the domestic public and political discussion repeatedly occurs over the $5 \%$ annual economic growth figure. But, in our view, such growth rates are not feasible for Russia in mid-term perspective. 
First, in the 2000s the economic growth in Russia was inter alia determined by a recovery after the transformation slowdown (a similar stage was observed in all CEE and former USSR countries) and a fourfold devaluation of the Russian rouble in 1998. These factors had a powerful potential for growth, but were unique and non-repeatable.

Second, as early as 2007 Russia experienced a limit of its productive capacities. Due to various reasons, no demanded structured reforms were carried out in 2008-2009, therefore the economy has approached its production possibility frontier in 2011-2012 once again. The signs of that are extremely low unemployment rate (currently the unemployment in Russia is lower that it was at the peak of economic boom in 2007-2008) and fast growth of labour costs along with virtually constant labour productivity. Notably, the capital utilisation ratio now is lower than in 2007, but this fact is related to the presence of morally or physically outdated capacities or to the impossibility of using that capital lacking qualified labour force.

Third, the demographic trends in Russia are extremely bad for economic development. Russia will loose several hundreds of thousands of working people annually in future years. Such a situation is unique - it is hard to find historical examples of economic development and growth in the presence of a permanently shrinking labour force. Increase in retirement age and liberalisation of migration procedures can solve only a part of the problem, as some retired people are already currently involved in production, but possible migrants are not numerous and qualified enough to address the economy's demand.

Fourth, in fact, Russia is in the middle-income trap now. In 2012 the GDP per capita reached \$20k (by PPP). Numerous international research shows that many countries faced a slow down in growth rates entering the GDP per capita interval of $\$ 15 \mathrm{k}-\$ 30 \mathrm{k}$. This was because of a need to change the economic model: low-income countries can grow at the expense of cheap production and commodities exported, but economies of high-income countries are based on production of high-technological goods, big international companies and a developed financial sector. The situation in Russia is aggravated by stagnation in the commodity sector, production costs are very high and there is no suitable institutional environment for establishing a modern non-commodity economy.

These arguments demonstrate that regarding the productive capacities the Russia can barely grow faster than 3-3,5\% annually, even with a favorable change in the global economy and restoration of investors' trust in emerging markets. Should the global uncertainty last, the available interval of GDP growth rates falls to $1,5-2,5 \%$, i.e. close to average growth rates in $\mathrm{EU}$ countries.

\section{Consumers' Demand}

Another traditional factor, stimulating economic growth, is domestic consumer demand. Unfortunately, we need to say that there are also serious problems in that field.
First, despite the relatively weak financial sector in Russia (total bank assets are around 60\% of GDP only), the population is heavily indebted. Though the total amount of outstanding loans to individuals amounts to as much as 1/6 of GDP, the population spends the same proportion of its disposable income to serve and repay the loans as the US population. The reason is extremely short loan maturity, low share of mortgage loans and very high nominal interest rates. Therefore, a further development of consumer demand at expense of bank credits is not economically reasonable and bears evident risks for the financial sector.

Second, an expansion of consumer demand at the expense of labour income is also unlikely. We have said that wages kept growing and employees' income increased, but people's expectations do not favour consumer-oriented behaviour. The inabililty of the economy to grow because of rising labour costs, leads to industrial restructuring and labour lay offs, which in turn makes labour cautious about their future incomes.

\section{The world is changing, traditional assump- tions are no longer valid, and the oil- and gas sector is not a key driver of Russian economic growth anymore.}

Third, the inconsistency of pension reform forces mean that more and more people care about pension provisions by themselves, thus stimulating saving, not spending. Currently savings are restrained partly by rather high and volatile inflation rates, but as inflation would go down and became more predictable (the Russian Central Bank has evident achievements on its way to bringing inflation down and shifting to inflation targeting regime), the motivation to save will be much more clear.

Thus, the Russian population seems to be rather a stingy saver paying its debts, not a rash consumer. This is a very important shift in a typical Russian individual's behavior compared to the 2000s and we need more time to think over and understand what it means for policy makers and all other parties in the Russian economy.

\section{Fiscal Misbalancing}

In the 2000s Russia was an example of responsible budget policy. After the 1998 crisis Russia paid off its foreign debts, kept federal budget surplus and accumulated sovereign commodity funds, as the external market conditions were favourable. In 2009-2010 the oil-based Reserve fund was the main source for financing the budget deficit and the anti-crisis package, while the public debt remains at minimum level (ca. 10\% of GDP). In 2012 the new budget rule was adopted, which secured balanced federal budget at the current level of oil prices. However, as early 


\section{If the President and the Government do not change the situation in those spheres in the near future, by 2018 (the next Presidential Elections) the country very likely will have an economy with extremely low or stagnating growth rates and a lot of macroeconomic misbalances.}

as within the next 3 years (the budget planning time horizon) this policy is endangered.

First, the tax base is shrinking. As I said earlier, taxes from the oil and gas sector provide more than $50 \%$ of total federal budget revenues, but the share of the oil and gas sector in GDP is going down. In addition, a bigger share of oil and gas production comes from new fields with special (preferential) tax regime. Thus, until 2016 we expect the tax revenues from oil and gas industry to drop by 1-1.5 p.p. of GDP. Under the low state of the market the tax revenues

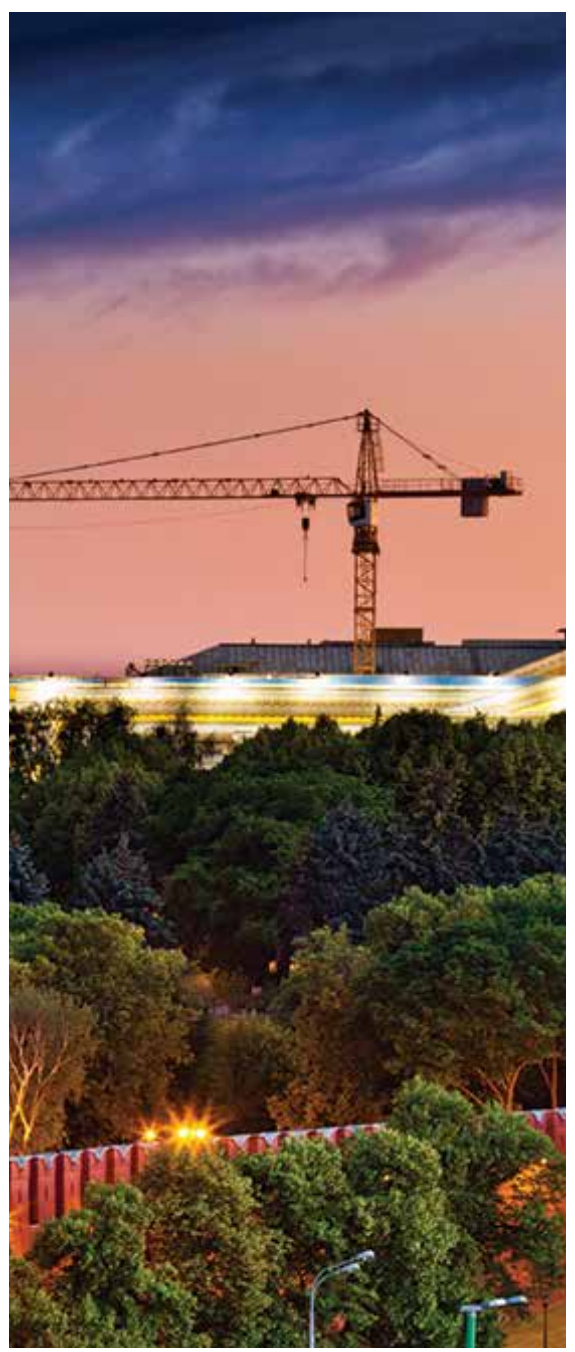

from non-oil and gas economy (e.g., corporate profit tax) are also low. And the federal budget deficit is likely to grow from the current $0.5-1 \%$ of GDP to 1.5 $2.5 \%$ of GDP at the expense of tax revenues shrinking only.

Second, the Russian Government actually rejected the pension reform, including an increase in retirement age (currently it is 60/55 years - the lowest level in Europe), the development of a saving pillar and a reduction in the list of professions with early retirement. Besides a negative impact on the labour market and undermining trust in government policy (in fact, the saving pillar was abolished soon after it got some popularity), the chosen reform design (in favour of dominating a distributive pillar) increases the risks of fragility of the pension system as well as all public finance. The deficit within the pension system will grow as the ratio of the working population and retired people shifts and the federal budget is the only source to the deficit.

Third, the structure of federal budget expenditure is not optimal and does not facilitate economic development. The expenditures on the human capital and quality of life (education, health care, infrastructure, ecology) are still low, but there are stable or even rising expenditures on the military-industrial complex, the army, police and low-effective support of state-owned and quasi-sate companies.

Fourth, the Government has nearly refused the budget rule now and does not accumulate money in the sovereign commodity funds (at still high oil prices). That means that in the case of the worse state of the global market the budget would not have enough reserves as in 2009-2010 and Russia would enter the debt market, but in a very bad time for borrowing.
All these arguments prove that Russia could face very serious problems with its public finance in the near future, and policy decisions (raise in taxes or public debt accumulation) would have very negative consequences for economic growth.

There are a lot of arguments illustrating the low probability of fast and stable growth of the Russian economy in midterm perspective. Does it mean that the economy is doomed and Russia will go down in the list of top economies? My answer - Yes and No. In fact, all the arguments are valid if we assume conservation of an institutional environment, current domestic business and investment climate. If the President and the Government do not change the situation in those spheres in the near future, by 2018 (the next Presidential Elections in Russia) the country very likely will have an economy with extremely low or stagnating growth rates and a lot of macroeconomic misbalances. But, if the institutional reforms take off, the country can quickly eliminate many of the mentioned constraints and take the path of stable economic development along with the global economy. E3?

\section{About the Author}

Sergey Drobyshevsky is Head of Macroeconomics and Finance Division of the Gaidar Institute for Economic Policy (Moscow, Russia) and Senior Research Fellow at the Russian Academy for National Economy and Public Service under the President of the Russian Federation, Doctor of Economics. His interests are in macroeconomics, monetary policy, financial institutions and financial markets, and economic forecasting. $\mathrm{He}$ is the author of 20 monographs and books published in Russia and abroad, and more than 100 research papers and articles. Since November 2012 he has been managing director of Russia's G20 Expert Council. 